\title{
CYCLIC SEDIMENTATION
}

A SYMPOSIUM on cyclic sedimentation was held in the Grant Institute of Geology of the University of Edinburgh during December 14-15, 1962, under the chairmanship of Profs. K. C. Dunham and T. S. Westoll. About 140 geologists attended the meeting, which was sponsored jointly by the Edinburgh Geological Society and the University of Edinburgh. Although the Carboniferous was, naturally enough, the subject of most papers a variety of cycles of different ages and facies was considered.

Differences in technique and approach emerged during the conference. The traditional stratigraphic approach was exemplified by Dr. G. A. L. Johnson, who dealt with the Visean and Namurian of northern England. In considering the development of the Yoredale cycles (marine limestone-shale-sandstone-seatearth-coal, in upward succession) he pointed out that a number of the basal limestone units were extremely persistent and certain distinctive horizons such as the Chaetetes and Calcifolium bands of the Great Limestone could be traced over almost the whole area. The basal limestones tend to split northwards with the intercalation of terrigenous deposits as they pass towards the old shoreline, while limestones associated with the top parts of cycles are usually highly variable in development.

Mr. P. McL. D. Duff and Dr. E. K. Walton emphasized that there was often a lack of objectivity in the description of cycles in coal-bearing sequences and cited examples of the resulting inconsistency and confusion. It was suggested that the number of occurrences of particular orders of sedimentary units should be the basis of a 'modal cycle' and that this should be distinguished from the 'composite sequence' and the 'ideal cycle', the former being built up from the many different lithologies which may occur in the succession and the latter being a theoretical model. The results of a study of the East Pennine Coalfield along these lines were described. The speakers also emphasized the great amount of variation, both vertical and lateral, of the Coal Measures sequence.

According to Dr. W. Schwarzacher a sedimentary sequence can be studied more appropriately by the methods of time-series analysis. In an investigated marine Carboniferous shale-limestone sequence in Ireland a shale percentage calculated for each $20-\mathrm{cm}$ interval gave the required numerical data. Two types of variation were found: a long-range trend consisting of alternating shale- and limestone-rich parts of the section which measure several tens of metres in thickness, and superimposed on this a much more regular limestone-shale oscillation with an approximate wave-length of 3 metres. The correlation structure of the shorter oscillation may be described by a high-order auto-regressive model. In geological terms, this could mean that a stable system of interdependent, environmental factors operated through long periods of time to generate the series. Alternatively, the same type of sedimentary record could be the result of a truly cyclic process in time.

Dr. Schwarzacher had also investigated the amount of shale per shorter oscillation in the stratigraphical sequence, and suggested that each oscillation could be interpeted as relating to a random burst of increased erosion.

Not surprisingly, arguments were adduced in favour of a variety of different causal mechanisms. Impressed by the lateral constancy of distinctive lithological horizons in the Yoredale cycles, Dr. Johnson and Prof. Dunham argued for regional diastrophic control, with the pronounced asymmetry of the cycles suggesting a periodic 'jerky' subsidence. This notion was taken up by Dr. M. H. P. Bott, who maintained that geophysical con- siderations favoured the formation of sedimentary basins as a by-product of the isostatic rise of a landmass repeatedly thrown out of balance by erosion. Flow of material in the upper mantle would probably be accompanied by local spasmodic foundering in the adjacent basins, associated with periodic faulting. Prof. F. H. Stewart, dealing with Permian evaporite deposits, saw in the larger repetitions of the normal salt sequence, with or without clastic material and normal marine carbonates (such as the main Zechstein cycles), the operation of relatively rapid subsidence of the bar (and presumably the basin) or, alternatively, the relatively rapid rise of sea-level followed by slower upward growth of the bar with or without fall in sea-level.

Sedimentary factors were emphasized by Dr. D. Moore, who described the great variability in a number of Yoredale cycles that he had investigated in detail. According to him, many of their features are consistent with the periodic building-out of a delta into a uniformly subsiding marine basin, the areas of active growth varying as the delta development lod to the progressive elimination of the gradient of the hinterland. The great variation in the Coal Measures led Mr. Duff and Dr. Walton also to conclude that sedimentary controls were predominant and that eustatic changes or regional diastrophic controls were quite unnecessary for all except perhaps three of the East Pennine Coal Measure cycles. Prof. T. S. Westoll presented a theoretical model of a Yoredale cycle in which an attempt was made to estimate the influence of compaction. Mr. J. R. L. Allen outlined the results of a thorough sedimentological analysis of continental cycles in the Lower Old Red Sandstone of the Anglo-Welsh Province. The standard cycle, several metres in thickness, shows a scoured surface followed by sandstones grading up into siltstones. Such cycles could be the result of simple wandering of river channels, variations of river base-level and/or variations in tectonic activity in the source area.

The role of differential subsidence was discussed by Messrs. W. A. Read and G. A. Goodlet. Evidence from the Scottish Carboniferous suggests that tectonic factors caused more or less continuous warping of the depositional surface and that the total subsidence in any area is related to the number of cycles in that area. Moreover, since it can be shown that strictly localized minor subsidenco could induce cyclic sedimentation in restricted areas while more or less uniform sedimentation was proceeding contemporaneously in adjacent areas, it is improbable that climatic or isostatic factors could have played an important part in the formation of such cycles.

The possibility of eustatic control of major sedimentary cycles in the marine Lias was dealt with by Dr. A. Hallam. These cycles, ranging normally in thickness from a few metres to a fow tens of metres, are characteristically represented in the off-shore facies by the sequence: condensed band-shale, passing up gradually into limestoneerosion surface. Criteria for distinguishing between eustatic and local tectonic control were outlined and it was proposed that on at least two occasions pronounced sedimentary and faunal changes in the Liassic auccession suggestive of widespread deepening of the sea correlated with major marine transgressions in several continents, indicating world-wide rise of sea-level.

In most cases the factor of time was avoided, but Prof. Stewart mentioned the very rogular small-scale layering in evaporites which had been interpreted as annual varving. On this basis the laminated rocks of the middle cycle of the Permian Lower Evaporites near Scarborough suggested that a relatively sudden change in rate of sub- 
sidence followed about 20,000 years of relative stability; after a further 5,000 years a greater change occurred. Dr. C. Downie described symmetrical cycles in the Kimeridge Clay consisting of clay-bituminous shale-oil shale-bituminous marl-coccolith limestone and the reverse sequence. These were probably attributable either to climatic (wet-dry) or tectonic (regression-transgression) changes. Dr. Downie estimated that the 170-200 cycles had developed during 6-8 million years, indicating a periodicity of between 30,000 and 47,000 years.

Notable points in the discussion of the papers presented during the symposium concermed whether the characteristic asymmetry of many sedimentary cycles necessarily implied fluctuating rates of change of the controlling mechanism, whether tectonic or eustatic, and the likely amount and cause of changes of sea-level in the Lias. Mr. W. A. Cummins raised the interesting point that major turbidite formations in the geosynclinal facies of the Anglo-Welsh Silurian appeared to correlate with likely times of high sea-level in the shelf facies.

The problem of terminology was, perhaps inevitably, left unresolved. It was instructive to have Mr. I. F. Sime (Ministry of Aviation) define cycles as a series of occurrences in which eonditions at the end of the series are the same as at the beginning-in recurrent cycles all series must be exactly similar. They could be represented mathematically by a sine wave, or related to a sine wave by a Fourier series. Alternatively impulses, which might be periodic or random, could trigger off successions of events which would be varied by local conditions, so that the series would not necessarily be similar in every case. In the limit, the series could be represented by one component.

A. HaLtam

E. K. WALTON

\title{
SOIL EROSION BY WATER
}

\begin{abstract}
THE realization of the urgent need of producing more food to meet the rapidly increasing requirements through the growth in world population has directed much attention to the question of controlling soil erosion. Erosion is a normal process and has indeed provided the parent material of soils on which we are dependent for crops. But it is clearly desirable to prevent or reduce the erosion of fertile soils in existence and serious losses of soils are undoubtedly attributable to the action of man. Soil conservation services have been set up in many countries with the view of persuading farmers to give up methods that may accelerate erosion and to adopt practices that will protect the soil and increase productivity.

The reason for erosion is quite well understood. When vegetation cover is removed, rain drops can move particles of soil and when the rainfall is heavy and greater than the rate of infiltration the excess water transports the soil particles. The eroding and transporting are functions of the velocity of the water movement and the properties of the soil particles. When the velocity increases from $\mathrm{I}$ to $2 \mathrm{ft}$. per sec, eroding power is increased 4 times and transporting power 32 times. Even relatively stable aggregates are dispersed by impact during a storm and can seal the soil surface; this starts run-off by the path of least resistance so that surface flow with fine particles in suspension moves into small channels which may develop into large gullies. The eroded soil may settle at distances
\end{abstract}

depending on particle size or be carried out to sea; some may be deposited in drainage channels or reservoirs or on growing crops and cause great damage. There are certain principles in the control of erosion which are easy to grasp. Keeping the soil covered with vegetation or with a mulch of residues obviously protects the surface from the impact of falling drops and improves the infiltration. Retention terraces, contour planting or strip cropping can prevent run-off or reduce its velocity to a balance with infiltration. Moreover, machines are available for earth-moving and seed-sowing in accordance with the best combined measures of husbandry and control.

These techniques have been proved in many landsthe United States, parts of Africa, Australia and New Zealand, Israel-and many bulletins on the subject have been published. Numerous specialists in the work have contributed information to the Agricultural Engineering Branch of the Water Development Division of the Food and Agriculture Organization of the United Nations, and in a recent paper, presented at an open meeting of the Institution of Agricultural Engineers at the Royal Society of Arts, on January 15, M. E. B. Neal summarizes the present position*. It contains a comprehensive list of services concerned with conservation and of publications on the subject.

A. M. Sмптн

* Journal of the Institution of Agricultural Engineers, 19, No. 1, 4 (1983).

\section{INFLUENCE OF THE EARTH'S CORE ON THE ORIGIN AND EVOLUTION OF LIFE}

\author{
By ROBERT J. UFFEN \\ University College of Arts and Science, University of Western Ontario, London, Ontario
}

T has generally been held that natural radiation-induced
mutations have not played any significant part in
biological evolution. However, the discovery of geo-
magnetically trapped, charged particle belts around the
Earth of intensity perhaps as high as $100 \mathrm{r}$./ h (refs. I and 2)
raises the possibility that the Earth's surface may have
been exposed in the past to ionizing radiation many
times greater than previously envisaged. Palæomagnetic
data ${ }^{3}$ indicate that the geomagnetic field intensity must
have been reduced to zero for intervals of several thousand
years ${ }^{4}$ which, while almost instantaneous on the geological
time-scale, would encompass many generations of living
organisms. During these intervals the trapped corpus-
cular radiation may have spilled on to the Earth, and
the solar wind would have been able to bathe the Earth, producing mutation rates many times greater than the spontaneous rates and thus capable of being a major influence in evolution in the presence of the environmental selection pressures of those times.

It is the purpose of this article to set forth qualitatively, the hypothesis that the thermal history of the Earth has determined the origin and development of its core, which has been a major factor in ovolution through its control of the main geomagnetic field ${ }^{5}$ and consequently of the charged particles which have been able to reach the Earth.

The argument involves the following process within the Earth: (a) The creation of a protocrust, protomantle and protocore by partial melting of the iron and silicates of the interior due to radioactive heating. The temperature 